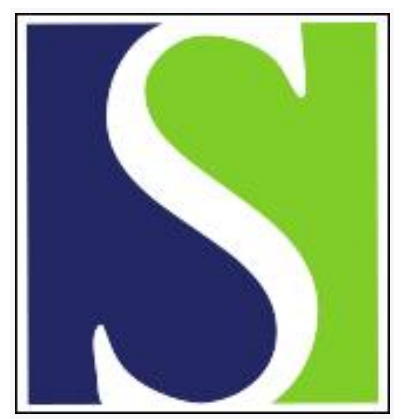

Scand J Work Environ Health 2011;37(4):325-331

https://doi.org/10.5271/sjweh.3153

Published online: 22 Feb 2011, Issue date: Jul 2011

Lung function, bronchial hyperresponsiveness, and atopy among firefighters

by Greven F, Krop E, Spithoven J, Rooyackers J, Kerstjens H, Heederik D

Affiliation: Frans Greven, Department of Environmental Health, Municipal Health Services, Hulpverleningsdienst, Groningen, PO Box 584, 9700 AN, Groningen, the Netherlands. f.greven@hvd.groningen.nl

Key terms: airway irritant; atopy; bronchial hyperresponsiveness; dose-response slope; firefighter; lung function; respiratory health; self-contained breathing apparatus

This article in PubMed: www.ncbi.nlm.nih.gov/pubmed/21340442 


\title{
Lung function, bronchial hyperresponsiveness, and atopy among firefighters
}

\author{
by Frans Greven, MSc, ${ }^{1,2}$ Esmeralda Krop PhD, ${ }^{2}$ Jack Spithoven, BSc, ${ }^{2}$ Jos Rooyackers MD, PhD, ${ }^{2}$ Huib \\ Kerstjens MD, PhD, ${ }^{3}$ Dick Heederik PhD ${ }^{3,4}$
}

\begin{abstract}
Greven F, Krop E, Spithoven J, Rooyackers J, Kerstjens H, Heederik D. Lung function, bronchial hyperresponsiveness, and atopy among firefighters. Scand J Work Environ Health. 2011;37(4):325-331. doi:10.5271/sjweh.3153

Objectives The aim of this study was to determine associations between lung function, bronchial hyperresponsiveness (BHR), and atopy with exposure to fire smoke among firefighters.

Methods The study was comprised of 402 firefighters, a randomly chosen subset of a previous survey among firefighters in the Netherlands. Subjects underwent spirometry and methacholine provocation, and blood samples were taken to assess atopy. Exposure to fire smoke was registered by a questionnaire.

Results Hyperresponsiveness expressed as dose-response slope (DRS) was positively and significantly associated with the number of fires fought in the last 12 months with and without adjustments for smoking, gender, atopy, age, and exposure in the main job held. Limiting the analysis to firefighters without exposure within 7 days of testing did not change any of the associations. The association between the number of fires and the DRS was stronger among atopics, and hyperresponsiveness expressed as $\mathrm{PD}_{20}$ was also significantly associated, indicating that atopics are at higher risk of developing BHR as a result of smoke exposure. Respiratory protection devices were not optimally used.
\end{abstract}

Conclusions It is recommended that awareness be heightened among firefighters to avoid exposure to all fire smoke and that management be sensitive to the adequate use of self-contained breathing apparatuses by their personnel.

Key terms airway irritant; dose-response slope; respiratory health; self-contained breathing apparatus.

Although firefighters have access to self-contained breathing apparatuses (SCBA) to prevent smoke inhalation, exposure to toxic hazards is a concern because the devices are not consistently used during firefighting, especially owing to the visual impression of low smoke concentration $(1,2)$. Previous studies have indicated that smoke exposure may result in acute lung function impairment $(3,4)$ and acute increase of airway responsiveness (5). Furthermore, studies have suggested that firefighters are at risk of chronic respiratory symptoms and lung function impairment (6-8). On the other hand, some studies did not find associations between exposure and lung function impairment $(9,10)$. Bronchial hyperresponsiveness (BHR) among firefighters has mostly been assessed shortly following exposure to fire smoke in a small population $(5,11)$ or following the World Trade Center disaster in New York, USA $(12,13)$. Miedinger et al $(6)$ found increased BHR in a population of 101 firefighters as compared to the Swiss general population. However, an association with levels of exposure was not demonstrated.

Information about the possible respiratory effects of firefighting has been collected in different countries over several decades. The use of SCBA has increased over the years though firefighter procedures vary in different parts of the world. Only few studies with sufficient power have been conducted among common firefighters, and little is known about potential respiratory health risks using modern breathing apparatuses. In this study, we investigated the respiratory health of firefighters in the Netherlands in relation to exposure to combustion products from fires.

1 Department of Environmental Health, Municipal Health Services Groningen, Groningen, the Netherlands.

2 Division of Environmental Epidemiology, Institute for Risk Assessment Sciences, Utrecht University, Utrecht, the Netherlands.

3 Department of Pulmonary Diseases, University Medical Center Groningen, University of Groningen, the Netherlands.

4 Julius Center for Health Sciences and Primary Care, University Medical Center Utrecht, Utrecht, the Netherlands.

Correspondence to: Frans Greven, Department of Environmental Health, Municipal Health Services, Hulpverleningsdienst, Groningen, PO Box 584, 9700 AN, Groningen, the Netherlands. [E-mail: f.greven@hvd.groningen.nl] 


\section{Methods}

\section{Population and design}

The current cross-sectional study was carried out in a subset of a population of firefighters from a previous study in the Netherlands (14). All tests were carried out at the fire stations between December 2008 and June 2009.

The institutional review board for human studies of the University Medical Centre Utrecht (Utrecht, the Netherlands) approved the protocol and written consent was obtained from all participants.

\section{Questionnaire and exposure estimates}

Questionnaire items have been previously described elsewhere (14). Due to the time lapse between the previous questionnaire and the execution of the tests at the fire stations (between 6 and 11 months), questions were asked again to (i) identify the type and number of incidents and the type, onset, and duration of symptoms following the last fire and (ii) determine possible exposure during an incident. Several personal exposure estimates were obtained by questionnaire items on working years as a firefighter, inhalation incidents ("have you ever inhaled a large amount of smoke"), the use of SCBA, the number of days since the last fire preceding the test, and the number of fires fought during the last 12 months. Additionally, job titles were reviewed for potential occupational exposure to airway irritants (dusts, gases, or fumes). The exposure was graded into no, possible, and certain exposure. Exposure in the main job was considered as a potential confounding variable.

\section{Serology}

Blood samples were processed within 4 hours and serum aliquots were stored at $-80^{\circ} \mathrm{C}$ until serologic assays were done. Specific immunoglobulin E (IgE) to common aeroallergens were analyzed in our laboratory based on adjusted, previously published methods (15) as a measure of atopy. In short, the common panel of allergens consisted of house dust mite, cat, dog, grass pollen mixture (Phleum Pratense and Lolium Perenne, protein 1:1), and birch pollen (Allergon AB, Angelholm, Sweden). Coating concentrations were: house dust mite (HDM) 10 , cat $15, \operatorname{dog} 10$, grass mixture 15 , and birch $20 \mu \mathrm{g}$ protein $/ \mathrm{ml}$. The final optical density (OD) signal was double corrected for the serum blank and the reagent blank. OD $>0.05$ was considered positive. Total IgE was measured as described elsewhere (15), using a detecting system consisting of polyclonal rabbit anti-human $\operatorname{IgE}$ 1:3500 (DAKO A00094, Dakopatts, Copenhagen, Denmark) and swine anti-rabbit/HrP (DAKO PO364) 1:3500 in physiological salt buffer (PBS) $0.05 \% \mathrm{v} / \mathrm{v}$ Tween 20 and $0.2 \% \mathrm{w} / \mathrm{v}$ gelatin. Performance remained equal to the original system. Atopy was defined as a positive reaction to the specific IgE panel or total $\operatorname{IgE}>100 \mathrm{kU} / 1$ $(16,17)$. We also explored specific atopy defined as positive reaction to the specific IgE panel (18).

\section{Spirometry and methacholine challenge}

Experienced technicians carried out the spirometry according to European Respiratory Society standards (19); results are presented as \% of predicted (20).

BHR was assessed by inhalation of increasing doses of methacholine delivered via a de Vilbiss 646 nebulizer chamber using a ZAN 200 breath triggered pump (Zan, Oberthulpa, Germany). Dosing was started with PBS followed by a $0.03 \mathrm{mg}$ methacholine dose after three quadrupling doses up to a cumulative dose of 1.92 $\mathrm{mg}$ (short schedule). Forced expiratory volume in one second $\left(\mathrm{FEV}_{1}\right)$ was measured 30 and 90 seconds after each challenge and the lowest $\mathrm{FEV}_{1}$ from a technically acceptable maneuver was used. After a fall in $\mathrm{FEV}_{1}$ of $5 \%$, doubling doses were used (long schedule). The test was stopped when a fall of $20 \%$ in $\mathrm{FEV}_{1}$ was observed $\left(\mathrm{PD}_{20}\right)$ or the maximum cumulative dose was reached. $\mathrm{BHR}_{20}$ was considered to be present if $\mathrm{PD}_{20} \leq 1.92 \mathrm{mg}$ methacholine. To make optimal use of all available data, we also calculated the dose-response slope (DRS) as the $\%$ fall in $\mathrm{FEV}_{1}$ per $\mathrm{mg}$ inhaled methacholine (21).

\section{Statistical analysis}

SAS version 9.1 statistical software was used (SAS Institute, Cary, NC). Associations between (log-transformed) exposure variables and continuous health outcomes were calculated using a linear regression analysis. Logistic regression was used to describe associations for binary health outcomes. The level of statistical significance was set at $\mathrm{P}<0.05$. Associations were adjusted for smoking, gender, atopy, and age. Effect modification was examined by analyzing atopic and non-atopic individuals separately and never smoking, formerly smoking, and currently smoking individuals separately.

\section{Results}

\section{Population characteristics}

In a previously conducted survey, 1249 active firefighters from 54 municipal fire brigades in 3 provinces of the Netherlands (Groningen, Friesland, and Drenthe) filled in a web-based version of the European Community respiratory health survey questionnaire (14). For our study, 21 fire brigades were randomly chosen until the 
required number of 400 firefighters was examined. The invited study population comprised 424 subjects, who had indicated in the previous survey that they were willing to participate. In total, 402 of 424 firefighters $(94.8 \%)$ were examined. Of 22 non-participating subjects, 13 could not fit in the planned schedule of measurements, 4 refused participation, 2 reported ill, 2 quit working as firefighter, and 1 was pregnant. One fire brigade consisted solely of professional firefighters; two fire brigades consisted of both professional and volunteer firefighters. The remaining fire brigades consisted for the most part of volunteers. All tests were carried out at fire stations between December 2008 and June 2009.

General characteristics of the study population and exposure estimates are shown in table 1 . Of 402 firefighters, 305 worked as volunteers, 60 as professionals, and 37 as both. Compared to males, females worked less time as firefighters $(\mathrm{P}<0.0001)$, were younger $(\mathrm{P}=0.002)$, fought their last fire preceding the examination longer ago ( $\mathrm{P}=0.0036)$, and used SCBA more often during the last fire they fought preceding the examination $(\mathrm{P}=0.006)$.

Occupational exposure to airway irritants in the main job was certain for 9 firefighters $(2.2 \%)$. For 325 firefighters (80.8\%) additional exposure seemed unlikely, and we had no information about job titles for 13 firefighters (3.2\%). For 55 firefighters (13.7\%), main job exposure seemed uncertain and therefore we conducted a sensitivity analysis considering this category once being exposed and once being not exposed.

Table 2 shows that, during the last fire fought before the examination, 344 subjects $(86.6 \%)$ did not use SCBA at all/all the time. Exposure to fire smoke was considered intolerable after a few minutes by 1 subject $(0.4 \%)$, discomforting by $48(20.4 \%)$, or perceptible by $162(68.9 \%)$.

\section{Symptoms}

Prevalence of respiratory symptoms ranged from $0.7 \%$ (asthma attack during last 12 months) to $10.0 \%$ (wheeze during last 12 months) (table 3). Prevalence of respiratory symptoms among medically tested subjects $(\mathrm{N}=402)$ did not differ from the prevalence of symptoms among the initial sample of firefighters who responded to the questionnaire $(\mathrm{N}=1249)$.

\section{Bronchial hyperresponsiveness, spirometry, and atopy}

BHR could not be determined for 10 subjects because (i) the spirometric maneuver was technically unacceptable $(\mathrm{N}=5)$, (ii) discomfort was experienced following the baseline lung function test ( $\mathrm{N}=3$ ), (iii) $\mathrm{FEV}_{1}$ was $<50 \%$ reference $(\mathrm{N}=1)$, or (iv) the individual was temporarily using oral corticosteroids $(\mathrm{N}=1)$. Serology was not available for 4 subjects either because insufficient blood was obtained $(\mathrm{N}=3)$ or provision of a blood sample was refused $(\mathrm{N}=1)$.

In table 4, BHR, baseline spirometry, and atopy are presented. $\mathrm{FEV}_{1}$ was higher among females $(\mathrm{P}=0.046)$, as were forced vital capacity $(\mathrm{FVC})(\mathrm{P}=0.001)$ and $\mathrm{FEV}_{1} / \mathrm{FVC}(\mathrm{P}<0.001)$. A total of 19 firefighters $(4.7 \%$, all male) showed a $\mathrm{FEV}_{1}$ below the lower limit of normal (LLN: defined as 1.645 times the standard deviation of predicted value), and 35 (8.7\%, all male) firefighters showed a $\mathrm{FEV}_{1} / \mathrm{FVC}$ below the LLN.

\section{Associations with exposure}

Hyperresponsiveness expressed as log-transformed DRS was associated with the log-transformed number of fires fought in the last 12 months (table 5). $\mathrm{BHR}_{20}$ was not associated with the number of fires fought [odds ratio (OR) $1.5,95 \%$ confidence interval $(95 \% \mathrm{CI}) 0.8-3.1]$.

Stratification for atopy showed a positive association of $\mathrm{BHR}_{20}$ with the number of fires fought with an OR of 4.9 (95\% CI 1.4-16.6) per 10 fires in atopic subjects, whereas among non-atopic individuals no association was found ( $\mathrm{OR} 0.8,95 \% \mathrm{CI} 0.3-1.9)$. This association became stronger after adjustment for smoking (OR 6.0, 95\% CI 1.6-22.0). Stratification for specific atopy showed also an association of $\mathrm{BHR}_{20}$ with the number of fires fought with an OR of 3.7 (95\% CI 1.1-12.9) per 10 fires among atopic subjects, whereas among non-atopic individuals no association was found (OR 0.9, 95\% CI 0.4-2.1). Again, this association became stronger after adjustment for smoking (OR 4.4, 95\% CI 1.2-16.5). Equally, the DRS was positively associated with number of fires fought among atopic subjects $(\beta=0.309, \mathrm{P}=0.03)$ after adjustment for smoking, whereas among non-atopic subjects no association was found $(\beta=0.091, \mathrm{P}=0.19)$. The DRS was borderline significantly associated with the number of fires fought among (specific) atopic subjects ( $\beta=0.349$, $\mathrm{P}=0.06$ ) after adjustment for smoking. Among non-atopic subjects, no association was found $(\beta=0.084, \mathrm{P}=0.18)$.

The aforementioned associations between hyperresponsiveness and the number of fires fought were hardly affected when we excluded subjects who had fought a fire within 7 days of testing. The association between exposure and $\mathrm{BHR}_{20}$ was hardly affected when cases with $\mathrm{FEV}_{1} / \mathrm{FVC}$ below LLN were excluded from the analysis (OR 4.6, 95\% CI 1.3-16.7) per 10 fires. No signs of effect modification were found for smoking.

The associations were also adjusted for exposure to airway irritants during the main job. A positive association was found between exposure to airway irritants and DRS $(\beta=0.734, \mathrm{P}<0.001)$ or $\mathrm{BHR}_{20}(\mathrm{OR} 4.6,95 \% \mathrm{CI}$ $1.2-17.7)$, when uncertain job exposure was defined as no additional exposure. When uncertain main job exposure was also designated as positive exposure the association with DRS became weaker $(\beta=0.132, \mathrm{P}=0.062)$ and the 
Table 1. Descriptive characteristics of the firefighters. [SD=standard deviation.]

\begin{tabular}{|c|c|c|c|c|c|c|c|c|c|c|c|c|c|c|c|c|c|c|c|}
\hline & \multicolumn{6}{|c|}{ Total } & \multicolumn{6}{|c|}{ Male } & \multicolumn{7}{|c|}{ Female } \\
\hline & $N$ & $\%$ & Mean & Range & $\mathrm{SD}$ & Median & $\mathrm{N}$ & $\%$ & Mean & Range & SD & Median & $\mathrm{N}$ & $\%$ & Mean & Range & $\mathrm{SD}$ & Median & P-value \\
\hline Gender & 402 & 100 & & & & & 356 & 88.6 & & & & & & 11.4 & & & & & \\
\hline Smoker & 111 & 27.7 & & & & & 100 & 28.1 & & & & & 11 & 24.4 & & & & & \\
\hline Ex-smoker & 115 & 28.7 & & & & & 102 & 28.7 & & & & & 13 & 28.9 & & & & & \\
\hline Age (years) & & & 41.3 & $20-60$ & 8.1 & & & & 41.8 & $20-60$ & 8.0 & & & & 37.9 & $22-53$ & 7.8 & & $<0.05$ \\
\hline $\begin{array}{l}\text { Length of } \\
\text { employment } \\
\text { as firefighter } \\
\text { (years) }\end{array}$ & & & 12.5 & $0-40$ & 8.5 & & & & 13.3 & $0-40$ & 8.6 & & & & 6.1 & $0-19$ & 4.8 & & $<0.05$ \\
\hline $\begin{array}{l}\text { Number of } \\
\text { fires fought } \\
\text { in the last } 12 \\
\text { months }\end{array}$ & & & 16.7 & $0-200$ & 18.9 & & & & 17.1 & $0-200$ & 19.6 & & & & 13.0 & $0-51$ & 11.8 & & \\
\hline $\begin{array}{l}\text { Inhalation } \\
\text { incident cases } \\
\text { ever }\end{array}$ & 139 & 34.8 & & & & & 122 & 34.6 & & & & & & 37.0 & & & & & \\
\hline $\begin{array}{l}\text { Time passed } \\
\text { since last fire } \\
\text { (days) }\end{array}$ & & & & & & $14.0^{\mathrm{a}}$ & & & & & & $14.0^{b}$ & & & & & & $35.5^{c}$ & $<0.05$ \\
\hline
\end{tabular}

association with $\mathrm{BHR}_{20}$ disappeared (OR 1.6, 95\% CI 0.8-3.1). Adjustment for the strict definition of main job exposure strengthened the relation between DRS and the number of fires $(\beta=0.159, \mathrm{P}=0.013)$. Adjustment for the lenient definition of exposure did not affect the association between DRS and number of fires $(\beta=0.144, \mathrm{P}=0.029)$.

No associations were found between the effect parameters, DRS and $\mathrm{BHR}_{20}$, and the exposure estimates, working years, inhalation incidents and the time passed since the last fire. Furthermore, DRS and $\mathrm{BHR}_{20}$ were not associated with any exposure, nor with the level of exposure during the last fire fought (data not shown).

No associations were found between exposure and baseline lung function (table 5). We adjusted for agedependency of lung function parameters comparing subjects $<25$ years with the reference values for 25 years $(20,22)$. Also peak expiratory flow (PEF) and maximum expiratory flow $\left(\mathrm{MEF}_{25}, \mathrm{MEF}_{50}\right.$, and $\left.\mathrm{MEF}_{75}\right)$ were not associated with exposure. No associations were found between any exposure estimate and atopy.

Table 2. Use of self-contained breathing apparatus during the last time firefighting preceding the examination.

\begin{tabular}{lccccc}
\hline & \multicolumn{3}{c}{ Not all the time } & & \multicolumn{2}{c}{ Not at all } \\
\cline { 2 - 3 } \cline { 5 - 6 } & $\mathrm{N}$ & $\%$ & & $\mathrm{~N}$ & $\%$ \\
\cline { 2 - 3 } & 136 & 34.3 & & 208 & 52.4 \\
$\begin{array}{l}\text { Use of self-contained } \\
\text { breathing apparatus }\end{array}$ & 110 & 27.7 & & 125 & 31.5 \\
$\begin{array}{l}\text { Unprotected exposure to } \\
\begin{array}{l}\text { visible smoke or inhalation } \\
\text { of smoke }\end{array}\end{array}$ & & & & \\
\hline
\end{tabular}

\section{Discussion}

We found a positive association between BHR and the number of fires fought in the last 12 months. Adjustment of the crude associations for gender, age, smoking, atopy, and exposure to airway irritants during the main job had no major effect. In addition, we found indications that atopics seem more at risk for BHR as a result of fire smoke exposure.

The questionnaire items "working years", "inhalation incidents", "number of days since the last fire", and "number of fires fought in the last 12 months" served as exposure estimates. Prior studies on the respiratory health of firefighters have mainly focused on respiratory symptoms and baseline lung function. Studies that assessed BHR among firefighters were mostly confined to acute response $(5,11)$ or the respiratory sequelae of the World Trade Center disaster (12, 13). Although Miedinger et al (6) found a higher prevalence of BHR in firefighters compared to a general Swiss population, a relation to length of employment as exposure estimate could not be demonstrated. However, in our study we found a positive relation between number of fires fought in the last 12 months and BHR $(\beta=0.146, P=0.03)$ adjusted for smoking. When we additionally adjusted for atopy and asthma, this association was slightly stronger ( $\beta=0.150, P=0.018$ ). In our analyses, we used two definitions of atopy: (i) a positive reaction to specific $\operatorname{IgE}$ or total $\operatorname{IgE}>100 \mathrm{kU} / 1$, and (ii) a positive reaction to specific IgE only. The results for both analyses were very 
Table 3. General respiratory symptoms

\begin{tabular}{lrr}
\hline General respiratory symptoms & \multicolumn{2}{c}{$\begin{array}{c}\text { Total } \\
\text { (N=402) }\end{array}$} \\
\cline { 2 - 3 } & $\mathrm{N}$ & $\%$ \\
\hline Wheeze during last 12 months & 40 & 10.0 \\
Wheeze and shortness of breath during last 12 months & 30 & 7.5 \\
Woken up by shortness of breath during last 12 months & 14 & 3.5 \\
Cough upon waking up during winter & 26 & 6.5 \\
Cough at day-/nighttime during winter & 38 & 9.5 \\
Phlegm at wake up during winter & 22 & 5.5 \\
Phlegm at day-/nighttime during winter & 20 & 5.0 \\
Dyspnoea when walking on a flat surface with people of & 4 & 1.0 \\
the same age & 34 & 8.5 \\
Have you ever had asthma? & 34 & 8.5 \\
Was the asthma doctor diagnosed? & 3 & 0.7 \\
Asthma attack during last 12 months & 10 & 2.5 \\
Current asthma medication & & \\
\hline
\end{tabular}

similar. The association between DRS and the number of fires fought became slightly weaker adjusted for specific IgE only, whereas this association was not affected when it was adjusted for smoking, job exposure and specific IgE simultaneously.

Acute effects of exposure to fire smoke can be ruled out as an explanation for our findings because associations were hardly affected when we limited the analysis to firefighters without exposure 7 days prior to testing $(\beta=0.148, P=0.047)$. Additionally, this association was not affected when we excluded 9 individuals for a second analysis to eliminate the possible effect of a subpopulation that had not yet fought a fire and worked $<6$ months as a firefighter $(\beta=0.162, \mathrm{P}=0.023)$. As the majority of firefighters were volunteers, we further explored the influence of occupational exposure to airway irritants other than during firefighter tasks. Although a positive association was found between main job exposure and BHR, the association between hyperresponsiveness and the number of fires fought in the last 12 months was not negatively affected after adjustment for this exposure. Furthermore, hyperresponsiveness was not related to any exposure during the last fire fought. Therefore, this result seems to be indicative of a persisting respiratory effect of smoke inhalation.

Associations of atopy and BHR have been described before $(23,24)$. In our study, the association of exposure to fire smoke with BHR was more pronounced among atopics. This is in line with other studies. Leuenberger et al (25) demonstrated that occupational exposure, particularly to dust and fumes, was associated with increased bronchial reactivity among "never smokers". The magnitude of the effect was larger among atopics. To our knowledge, effect modification of BHR for atopy has not been demonstrated before in the case of exposure to fire smoke.

We found no relation between exposure estimates and baseline lung function parameters $\left[\mathrm{FEV}_{1}, \mathrm{FVC}\right.$, PEF, maximal mid-expiratory flow (MMEF), $\mathrm{MEF}_{25}$, $\mathrm{MEF}_{50}$ and $\mathrm{MEF}_{75}$ ]. We performed several sensitivity analyses, from which firefighters with possible exposure within 7 days of testing were excluded. The shown data were adjusted for age-dependency of lung function parameters comparing subjects $<25$ years with the reference values for 25 years $(20,22)$. Additional sensitivity analyses were performed without adjustments for age-dependency and adjustment for age-dependency $\leq 30$ years. Again, no associations were demonstrated between any exposure estimate and baseline lung function parameters. We stratified the population for atopy and smoking behavior both separately and combined. No indications for effect modification were found. In addition, adjustment for smoking behavior by categories (never smoking, formerly smoking, and currently smoking) as well as by pack-years did not provide any evidence of effect modification.

This study was executed as a subset of an earlier study (14). The response rate of the participants of 21 randomly chosen fire brigades invited for the testing at the fire stations was $94.8 \%$, and, therefore, selection bias was deemed improbable. General respiratory symptoms did not differ between both populations. Comparison with the Dutch version of the European Community respiratory health survey [European Respiratory Health Study the Netherlands (ELON)] (26), showed a statistically lower prevalence of several respiratory symptoms among firefighters compared with a Dutch general population. OR ranged from 0.3 (95\% CI 0.2-0.5) for "phlegm at day-/nighttime during winter" to 0.5 (95\% CI 0.3-0.7) for "woken up by shortness of breath during the last 12 months". There was a significantly elevated prevalence of firefighters who "ever had asthma" compared to the ELON population with an OR of 1.5 (95\% CI 1.1-2.0). These findings are also in line with the comparison between the questionnaire study and ELON (14). Therefore, selection bias seems unlikely. A healthy worker effect, in combination with the selection of both professional and volunteer firefighters by mandatory pre-employment and periodical medical examinations, might explain the relatively low prevalence of general respiratory symptoms among firefighters. In this light, the relatively high prevalence of asthma based on the questionnaire study among firefighters, supported by the methacholine provocation data, is remarkable.

It is notable that an association was found between BHR and the number of fires fought, whereas no association existed with the number of working years. A likely explanation is that the number of fires fought can vary widely per working year and the number of fires is therefore a better estimate of exposure. 
Table 4. Lung function, bronchial hyperresponsiveness (BHR), and atopy. $\left[\mathrm{FEV}_{1}=\right.$ forced expiratory volume in one second; $F V C=$ forced vital capacity; MMEF=maximal mid-expiratory flow; DRS=dose-response slope.]

\begin{tabular}{|c|c|c|c|c|c|c|c|c|c|c|c|c|c|c|c|c|c|c|}
\hline & & & All $(\mathrm{N}=402)$ & & & & & & ale $(\mathrm{N}=355)$ & & & & & & Female $(\mathrm{N}=$ & 46) & & \\
\hline & $\mathrm{N} \quad \%$ & Mean & Range & SD & Median & $\mathrm{N}$ & $\%$ & Mean & Range & SD & Median & $\mathrm{N}$ & $\%$ & Mean & Range & SD & Median $\mathrm{P}$ & P-value \\
\hline $\begin{array}{l}\mathrm{FEV}_{1} \% \\
\text { predicted }\end{array}$ & & 101.6 & $50.7-138.7$ & 12.8 & & & & 101.1 & $50.7-138.7$ & 12.7 & & & & 105.1 & $82.3-131.1$ & 12.9 & & $<0.05$ \\
\hline $\begin{array}{l}\text { FVC \% } \\
\text { predicted }\end{array}$ & & 107.9 & $70.6-149.2$ & 12.3 & & & & 107.2 & $70.6-149.2$ & 11.8 & & & & 113.4 & $92.8-144.1$ & 14.2 & & $<0.05$ \\
\hline $\begin{array}{l}\mathrm{FEV}_{1} \mathrm{a}^{2} \\
\mathrm{FVC}^{2} \%\end{array}$ & & 77.3 & $52.1-97.1$ & 6.3 & & & & 76.9 & $52.1-90.5$ & 6.4 & & & & 80.5 & $71.2-97.1$ & 4.7 & & $<0.05$ \\
\hline MMEF \% & & 82.2 & $18.0-145.0$ & 22.1 & & & & 81.8 & $18.0-145.0$ & 22.4 & & & & 86.1 & $53.5-128.8$ & 19.0 & & \\
\hline $\mathrm{BHR}_{20}$ & 6316.1 & & & & & 52 & 15.0 & & & & & & 23.9 & & & & & \\
\hline DRS & & & & & $4.2^{b}$ & & & & & & $4.2^{c}$ & & & & & & $4.7^{d}$ & \\
\hline Atopy & 12631.3 & & & & & 115 & 32.3 & & & & & & 23.9 & & & & & \\
\hline $\begin{array}{l}\text { Specific } \\
\text { atopy }\end{array}$ & 9323.1 & & & & & 85 & 23.9 & & & & & & 17.4 & & & & & \\
\hline
\end{tabular}

Table 5. Factors affecting lung function and methacholine provocation parameters $\left[\mathrm{FEV}_{1}=\right.$ forced expiratory volume in one second; FVC=forced vital capacity; MMEF=maximal mid-expiratory flow; DRS=dose-response slope.]

\begin{tabular}{|c|c|c|c|c|}
\hline & Exposure parameter & Coefficient & P-value & $r^{2}$ \\
\hline \multirow[t]{4}{*}{$\mathrm{FEV}_{1}^{\mathrm{a}}$} & Number of fires & -0.008 & 0.90 & 0.441 \\
\hline & Inhalation incident & -0.042 & 0.46 & 0.444 \\
\hline & Working years & -0.024 & 0.80 & 0.439 \\
\hline & Time passed since last fire & -0.0004 & 0.31 & 0.442 \\
\hline \multirow[t]{4}{*}{ FVC a } & Number of fires & -0.021 & 0.78 & 0.520 \\
\hline & Inhalation incident & -0.089 & 0.18 & 0.522 \\
\hline & Working years & -0.015 & 0.89 & 0.519 \\
\hline & Time passed since last fire & -0.0005 & 0.33 & 0.521 \\
\hline \multirow{4}{*}{$\begin{array}{l}\mathrm{FEV}_{1} / \\
\mathrm{FVC}^{\mathrm{a}}\end{array}$} & Number of fires & 0.122 & 0.87 & 0.085 \\
\hline & Inhalation incident & 0.326 & 0.61 & 0.083 \\
\hline & Working years & -0.181 & 0.87 & 0.085 \\
\hline & Time passed since last fire & 0.0003 & 0.95 & 0.084 \\
\hline \multirow[t]{4}{*}{ MMEF a } & Number of fires & -0.819 & 0.77 & 0.013 \\
\hline & Inhalation incident & 1.791 & 0.45 & 0.014 \\
\hline & Working years & -2.658 & 0.51 & 0.013 \\
\hline & Time passed since last fire & -0.001 & 0.96 & 0.012 \\
\hline \multirow[t]{4}{*}{ DRS b, c } & Number of fires $\mathrm{C}$ & 0.146 & 0.03 & 0.014 \\
\hline & Inhalation incident & -0.006 & 0.91 & 0.001 \\
\hline & Working years c & 0.028 & 0.68 & 0.001 \\
\hline & Time passed since last fire & 0.0002 & 0.67 & 0.001 \\
\hline
\end{tabular}

a Adjusted for smoking, height and age.

${ }^{b}$ Adjusted for smoking.

c Log-transformed.
The fact that BHR was associated with the number of fires fought in the last 12 months, particularly among atopic firefighters, might be due to the poor compliance in using SCBA. As mentioned in other studies, the devices are often not used or not used all the time when fighting a fire, especially owing to the visual impression of low smoke concentration. Our results suggest that the use of SCBA should be encouraged even at low-level smoke concentrations.

\section{Acknowledgements}

The authors wish to thank the personnel of the fire brigades of the provinces of Groningen, Friesland, and Drenthe for their cooperation in this study. In addition, the authors would like to thank Renee Lokman, Theresia Offinga, Ellen Kreeft, Elzo Gankema, Ester de Vries, Maria Smith, Reina Niestijl, Roelina Smid, Walburga Gulker, Harriëtte Smidt, Elly van der Esch, Yvonne Valkema, Margriet van der Eems, Tessa Bakker, Jacqueline Aalfs, Mischa Zengeni, Els Greven, and Ali Karimi for their contribution to the field work. This study was supported in part by grant for project number 7135.0005 from the Netherlands Organisation for Health Research and Development (ZonMW, The Hague). The authors declare they have no competing financial interests. 


\section{References}

1. Brandt-Rauf PW, Fallon LF, Jr., Tarantini T, Idema C, Andrews L. Health hazards of fire fighters: exposure assessment. Br J Ind Med 45:606-612, 1988

2. Burgess JL, Nanson CJ, Bolstad-Johnson DM, Gerkin R, Hysong TA, Lantz RC, Sherrill DL, Crutchfield CD, Quan SF, Bernard AM, Witten ML. Adverse respiratory effects following overhaul in firefighters. J Occup Environ Med 43:467-473, 2001. doi:10.1097/00043764-200105000-00007.

3. Brandt-Rauf PW, Cosman B, Fallon LF, Jr., Tarantini T, Idema C. Health hazards of firefighters: acute pulmonary effects after toxic exposures. Br J Ind Med 46:209-211, 1989.

4. Large AA, Owens GR, Hoffman LA. The short-term effects of smoke exposure on the pulmonary function of firefighters. Chest 97:806-809, 1990. doi:10.1378/chest.97.4.806.

5. Chia KS, Jeyaratnam J, Chan TB, Lim TK. Airway responsiveness of firefighters after smoke exposure. $\mathrm{Br} \mathrm{J}$ Ind Med 47:524-527, 1990.

6. Miedinger D, Chhajed PN, Stolz D, Gysin C, Wanzenried AB, Schindler C, Surber C, Bucher HC, Tamm M, Leuppi JD. Respiratory symptoms, atopy and bronchial hyperreactivity in professional firefighters. Eur Respir J 30:538-544, 2007. doi:10.1183/09031936.00015307.

7. Mustajbegovic J, Zuskin E, Schachter EN, Kern J, VrcicKeglevic M, Heimer S, Vitale K, Nada T. Respiratory function in active firefighters. Am J Ind Med 40:55-62, 2001. doi:10.1002/ajim.1071.

8. Ribeiro M, de Paula SU, Bussacos MA, Terra-Filho M Prevalence and risk of asthma symptoms among firefighters in Sao Paulo, Brazil: a population-based study. Am J Ind Med 52:261-269, 2009. doi:10.1002/ajim.20669.

9. Loke J, Abrams C, Virgulto J. Lung function in fire fighters. Conn Med 56:179-183, 1992.

10. Musk AW, Peters JM, Bernstein L, Rubin C, Monroe CB. Pulmonary function in firefighters: a six-year follow-up in the Boston Fire Department. Am J Ind Med 3:3-9, 1982. doi:10.1002/ajim.4700030103.

11. Sherman CB, Barnhart S, Miller MF, Segal MR, Aitken M, Schoene R, Daniell W, Rosenstock L. Firefighting acutely increases airway responsiveness. Am Rev Respir Dis 140:185190, 1989.

12. Banauch GI, Alleyne D, Sanchez R, Olender K, Cohen HW, Weiden M, Kelly KJ, Prezant DJ. Persistent hyperreactivity and reactive airway dysfunction in firefighters at the World Trade Center. Am J Respir Crit Care Med 168:54-62, 2003. doi:10.1164/rccm.200211-1329OC.

13. Prezant DJ, Weiden M, Banauch GI, McGuinness G, Rom WN, Aldrich TK, Kelly KJ. Cough and bronchial responsiveness in firefighters at the World Trade Center site. N Engl J Med 347:806-815, 2002. doi:10.1056/NEJMoa021300.

14. Greven FE, Rooyackers JM, Kerstjens HA, Heederik DJ. Respiratory symptoms in firefighters. Am J Ind Med. 2011 Jan 18. doi: 10.1002/ajim.20929. [Epub ahead of print].
15. Doekes G, Douwes J, Wouters I, de WS, Houba R, Hollander A. Enzyme immunoassays for total and allergen specific IgE in population studies. Occup Environ Med 53:63-70, 1996. doi:10.1136/oem.53.1.63

16. Bernard A, Carbonnelle S, De BC, Michel O, Nickmilder M. Chlorinated pool attendance, atopy, and the risk of asthma during childhood. Environ Health Perspect 114:1567-1573, 2006. doi:10.1289/ehp.8461.

17. Brooks SM, Hammad Y, Richards I, Giovinco-Barbas J, Jenkins K. The spectrum of irritant-induced asthma: sudden and not-so-sudden onset and the role of allergy. Chest 113:4249, 1998. doi:10.1378/chest.113.1.42.

18. Krishnan KR, Peterson EL, Wegienka G, Havstad S, Johnson CC, Zoratti EM, Ownby DR. Pattern of allergen-specific IgE sensitization relative to total serum IgE concentration in young adults. Ann Allergy Asthma Immunol 105:401-403, 2010. doi:10.1016/j.anai.2010.09.014.

19. Pellegrino R, Viegi G, Brusasco V, Crapo RO, Burgos F, Casaburi R, Coates A, van der Grinten CP, Gustafsson P, Hankinson J, Jensen R, Johnson DC, MacIntyre N, McKay R, Miller MR, Navajas D, Pedersen OF, Wanger J. Interpretative strategies for lung function tests. Eur Respir J 26:948-968, 2005. doi:10.1183/09031936.05.00035205.

20. Quanjer PH, Tammeling GJ, Cotes JE, Pedersen OF, Peslin $\mathrm{R}$, Yernault JC. Lung volumes and forced ventilatory flows. Report Working Party Standardization of Lung Function Tests, European Community for Steel and Coal. Official Statement of the European Respiratory Society. Eur Respir J Suppl 16:5-40, 1993

21. O'Connor G, Sparrow D, Taylor D, Segal M, Weiss S. Analysis of dose-response curves to methacholine. An approach suitable for population studies. Am Rev Respir Dis 136:1412-1417, 1987.

22. Robbins DR, Enright PL, Sherrill DL. Lung function development in young adults: is there a plateau phase? Eur Respir J 8:768-772, 1995.

23. Woolcock AJ, Peat J. What is the relationship between airway hyperresponsiveness and atopy? Am J Respir Crit Care Med 161:S215-S217, 2000.

24. Nowak D, Heinrich J, Jorres R, Wassmer G, Berger J, Beck E, Boczor S, Claussen M, Wichmann HE, Magnussen $\mathrm{H}$. Prevalence of respiratory symptoms, bronchial hyperresponsiveness and atopy among adults: west and east Germany. Eur Respir J 9:2541-2552, 1996. doi:10.1183/090 31936.96.09122541.

25. Leuenberger $P$, Schindler C, Schwartz J, Ackermann-Liebrich U, Tara D, Perruchoud AP, et al. Occupational exposure to inhalative irritants and methacholine responsiveness. Scand J Work Environ Health 26:146-152, 2000.

26. Rijcken B, Kerkhof M, De Graaf A, Boezem HM, Droste JHJ, Kremer AM. Europees Luchtweg Onderzoek Nederland (ELON) [European Respiratory Health Study the Netherlands]; Groningen: University of Groningen. 1996.

Received for publication: 9 November 2010 